

\section{DISCLAIMER}

This report was prepared as an account of work sponsored by an agency of the United States Government. Neither the United States Government nor any agency Thereof, nor any of their employees, makes any warranty, express or implied, or assumes any legal liability or responsibility for the accuracy, completeness, or usefulness of any information, apparatus, product, or process disclosed, or represents that its use would not infringe privately owned rights. Reference herein to any specific commercial product, process, or service by trade name, trademark, manufacturer, or otherwise does not necessarily constitute or imply its endorsement, recommendation, or favoring by the United States Government or any agency thereof. The views and opinions of authors expressed herein do not necessarily state or reflect those of the United States Government or any agency thereof. 


\section{DISCLAIMER}

Portions of this document may be illegible in electronic image products. Images are produced from the best available original document. 


\section{LEGAL NOTICE}

This report was prepared as an account of Government sponsored work. Neither the United States, nor the Atomic Energy Commission, nor any person acting on behalf of the Commission:

A. Makes any warranty or representation, expressed or implied, with respect to the accuracy, completeness, or usefulness of the information contained in this report, or that the use of any information, apparatus, method, or process disclosed in this report may not infringe privately owned rights; or

B. Assumes any liabilities with respect to the use of, or for damages resulting from the use of any information, apparatus, method, or process disclosed in this report.

As used in the above, "person acting on behalf of the Commission" includes any employee or contractor of the Commission, or employee of such contractor, to the extent that such employee or contractor of the Commission, or employee of such contractor prepares, disseminates, or provides access to, any information pursuant to his employment or contract with the Commission, or his employment with such contractor.

Printed in the United States of America Available from

Clearinghouse for Federal Scientific and Technical Information National Bureau of Standards, U. S. Department of Commerce

Springfield, Virginia 22151

Price: Printed Copy $\$ 3.00$; Microfiche $\$ 0.65$ 


\section{DISSOLUTION OF IMPURE PLUTONIUM TETRAFLUORIDE IN NITRIC ACID}

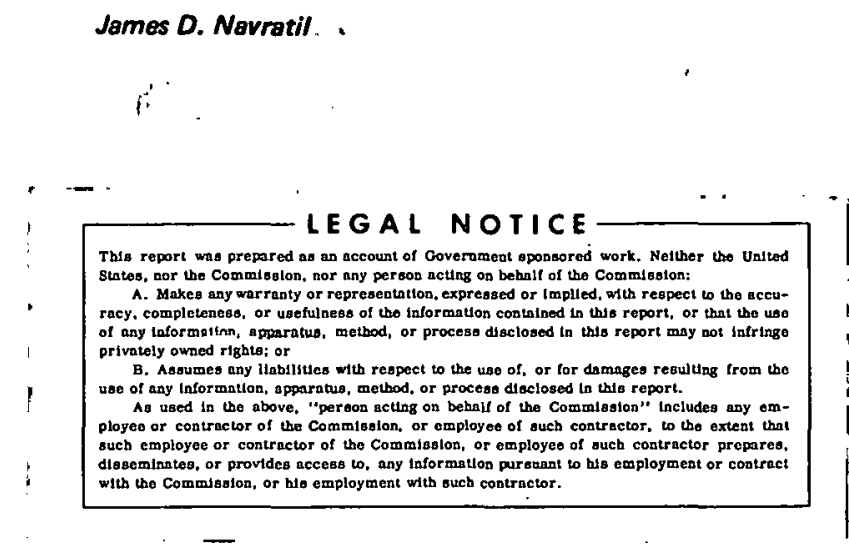

5

THE DOW CHEMICAL COMPANY

P. O. BOX 888

GOLDEN, COLORADO 80401 .

Prepared under Controct AT(29-1)-1106

for the

Albuquerque Operations Office

U. S. Atomic Energy Commission 
RFP-1 118 


\section{CONTENTS}

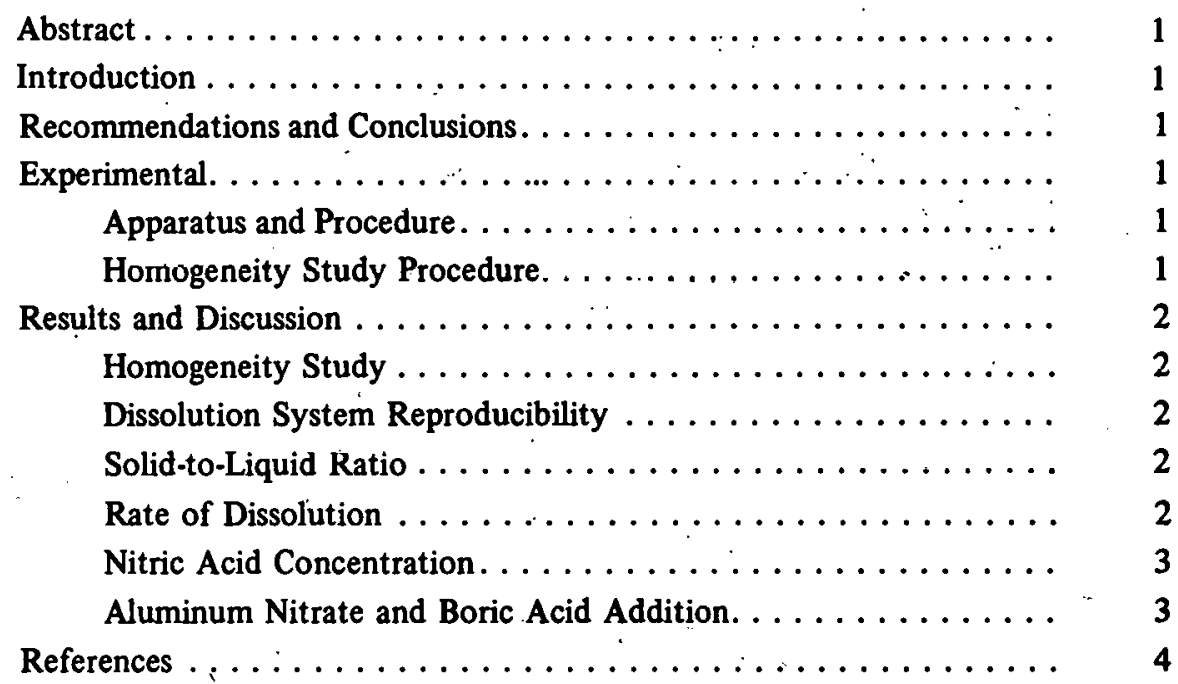




\section{ACKNOWLEDGMENT}

The author is indebted to Frend J. Miner for his technical assistance and Yvonne M. Ferris for performing the statistical analyșes. I alsn arknowlodge tho X-ray Fluurescence Laboratory Group, which is under the direction of N. E. Moody, for their cooperation in performing the plutonium analyses. 


\title{
DISSOLUTION OF IMPURE PLUTONIUM TETRAFLUORIDE IN NITRIC ACID
}

\author{
James D. Navratil
}

\begin{abstract}
The optimum dissolution conditions were found for impure plutonium tetrafluoride (major impurities: $\mathrm{PuO}_{2}$ and $\mathrm{MgO}$ ). They are: nitric acid concentration of 12 to 14 molar, reflux and stirring for up to two hours, solidto-liquid ratio of 100 to $1.50 \mathrm{~g} / \mathrm{l}$, and addition of boric acid or aluminum nitrate.
\end{abstract}

\section{INTRODUCTION}

The Rocky Flats plutonium recovery operation aćcumulates plutonium tetrafluoride which is unsuitable for reductions because it is too contaminated with impurities. Presently this impure tetrafluoride is dissolved by refluxing for $3-4$ hours in batch pots using 4 liters of $12.5 \mathrm{M} \mathrm{HNO}$ with charges of 1000 grams. This procedure is time-consuming and inefficient for recycling this plutonium. A dissolution study was initiated to deternine the optimum conditions for dissolution. This report summarizes the results of this study. The following factors were investigated:

- The optimum solid-to-liquid ratio.

- The rate of dissolution.

- The optimum nitric acid concentration.

- The effect of aluminum nitrate and boric acid.

\section{RECOMMENDATIONS AND CONCLUSIONS}

The optimum conditions determined for maximum dissolution of impure plutonium tetrafluoride (major constituents besides $\mathrm{PuF}_{4}$ were $\mathrm{PuO}_{2}$ and $\mathrm{MgO}$ ) in $\mathrm{HNO}_{3}$ at refluxing temperatures were as follows:

1. A solid-to-liquid ratio of 100 to $150 \mathrm{~g} / \mathrm{l}$.

2. Reflux and stirring for up to 2 hours.

3. Nitric acid concentration of 12-14 molar.

4. Addition of boric acid or aluminum nitrate as a fluoride complexing agent.
The optimum conditions are recommended for production experimentation. The optimum parameters for dissolution should be studied on a production scale. If a fluoride ion complexing agent is used, contamination of the plutonium by this agent after peroxide precipitation should be investigated.

\section{EXPERIMENTAL}

Apparatus and Procedure: The dissolution of plutonium tetrafluoride was performed in a 125 -ml Florence flask containing 25.0 grams of solid and 100 milliliters of the desired solvent. The contents of the flask were refluxed and stirred on a Thermolyne stir plate for 2.0 hours. The flask was fitted with a 12-inch long condenser to maintain. solution volume.

After the stirring was terminated, the condenser was washed with $0.5 \mathrm{M} \mathrm{HNO}_{3}$ and the solution cooled. Next, the solution was filtered through Whatman No. 42 filter paper into a $250-\mathrm{ml}$ volumetric flask. The residue was washed with $0.5 \mathrm{M} \mathrm{HNO}_{3}$ until the $250-\mathrm{ml}$ mark was reached. Finally the solution was mixed, sampled in duplicate, and each sample analyzed twice for plutonium by $\mathrm{x}$-ray fluorescence.

Homogeneity Study Procedure: The batch of impure plutonium tetrafluoride used was obtained from the production fluorination of calcined plutonium peroxide. The material is typical of the plutonium tetrafluoride which is recycled due to impurities. Major constituents were $\mathrm{PuF}_{4},>10 \% \mathrm{PuO}_{2},>10 \% \mathrm{MgO}$. Minor constituents were $\mathrm{Fe}$ and Ni. This material was ground in a mortar and screened through a Tyler 40 mesh screcn before using. Approximately $0.1 \%$ of the material did not screen and was identified by $x$-ray diffraction as nickel fluoride and nickel oxide.

The screened batch of impure plutonium tetrafluoride was blended and sampled six times for a homogeneity study. Each sample was analyzed twice for $\mathrm{g} / \mathrm{g}$ Pu, surface area, crystallite size, percent fluoride, percent $\mathrm{PuO}_{2}$ and $\mathrm{Fe}$ concentration. The percent $\mathrm{PuO}_{2}$ was found greater than $10 \%$. Since no value was obtained for $\mathrm{PuO}_{2}$ contents the x-ray peak area was used for a comparison of homogeneity. 


\section{RESULTS AND DISCUSSION}

Homogeneity Study: Table I contains the results of the homogeneity study. The means of the sample results were no more varibale than the individual results from each sample, except for percent fluoride and ppm of iron. The results indicate the tetrafluoride used was statistically homogeneous.

Dissolution System Reproducibility: Twenty-five grams of the tetrafluoride were refluxed and stirred for 2 hours using $12 \mathrm{M} \mathrm{HNO}_{3}$ as described in the experimental procedure. This operation was repeated 8 times, and the results are shown in Table II.

The standard deviation of the percent plutonium dissolved fiom elght samples run under the above conditions was 2.18. This error was probably the total error involved in the results. Although the data presented have not been corrected for this error, it was considered when the conclusions were made.

Solid-to-Liquid Ratio: Plutonium tetrafluoride samples $(10,15,20,22.5,25,30$ and 35 grams) were contacted with $100 \mathrm{ml}$ of $12 \underline{\mathrm{M} \mathrm{HNO}} \mathrm{HN}_{3}$ for 2 hours as described in the experimental procedure. The effects of these various solid-to-liquid ratios on the dissolution of plutonium tetrafluoride are shown in Table III. In general, the percent plutonium dissolved is greater for the lower solid-to-liquid ratio.
Table 1I. Reproducibility of dissolution system.
Solvent:

Reflux Period:

Solid-to-Liquid Ratio:

Experiment Number

*Standard Deviation $=2.18$

1
2
3
4
5
6
7
8

$12 \mathrm{M} \mathrm{HNO}_{3}$

2 hours

$250 \mathrm{~g} / 1$

Plutonium Dissolved (\%)*
52.1

54.5

50.7

50.9

55.4

53.9

56.6

51.8
The same trend as shown in Table III for solid-to-liquid ratios was found using "clean" plutonium tctrafluoride.

Rate of Dissolution: Figure 1 shows the effect of reflux and stir time on dissolution. Plutonium tetrafluoride ( $25 \mathrm{~g}$ per $100 \mathrm{ml}$ of $12 \mathrm{M} \mathrm{HNO}_{3}$ ) was stirred at refluxing temperatures for $0.5,1,2,3,4,6$ and 8 hours and the plutonium concentration measured. The rate of dissolution (slope of the curve) decreases after 2 hours as found with previous work using "clean" plutonium tetrafluoride. ${ }^{1}$

Table I. Homogeneity of impure plutonium tetrafluoride (six samples analyzed in duplicate).

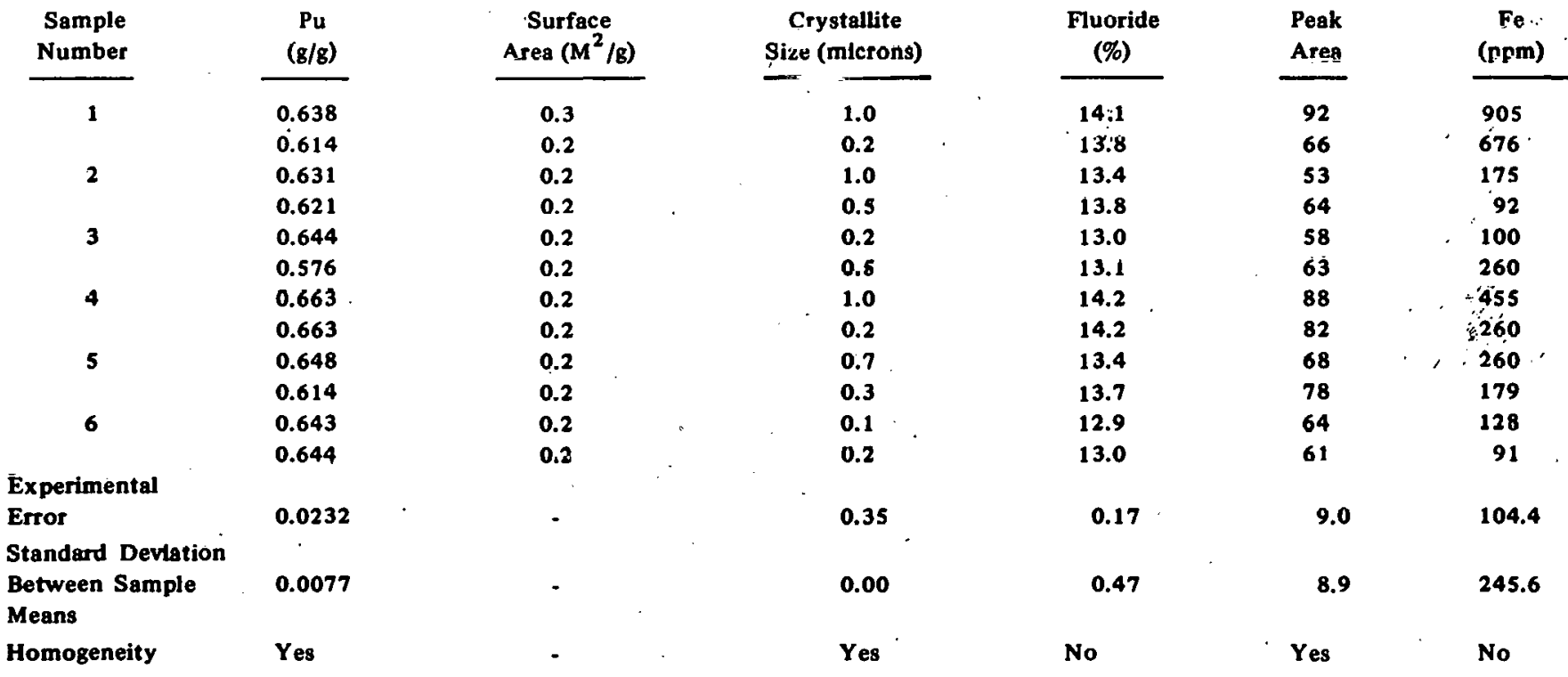


Table III. The effect of the solld-to-liquild ratio on the dissolution of plutonium tetrenuoride.

$\begin{array}{ll}\text { Solvent: } & 12 \mathrm{M} \mathrm{HNO}_{3} \\ \text { Reflux Period: } & 2 \text { hours: }\end{array}$

Solld-to-Liquid Ratio ( $/ / 1)$

\begin{tabular}{c} 
Plutonium Dissolved (\%) \\
\hline 90.9 \\
70.0 \\
51.6 \\
55.8 \\
55.5 \\
48.9 \\
47.9
\end{tabular}

100
150
200
225
250
300
350

Nitric Acid Concentration: The effect of several nitric acid concentrations on the dissolution of plutonium tetrafluoride is shown in Table IV. The dissolution was performed as described in the experimental procedure. The nitric acid concentration for optimum dissolution is between 12 and 14 molar. Maximum dissolution of "clean" plutonium tetrafluoride was obtained

Figure 1. The effect of refiux and atir time on the diseolution rate of plutonium totrafuorido (cotvent 12M $\mathrm{HNO}_{3}$ colid-toliquid ntio $250 \mathrm{~g} / \mathrm{l}$ ).

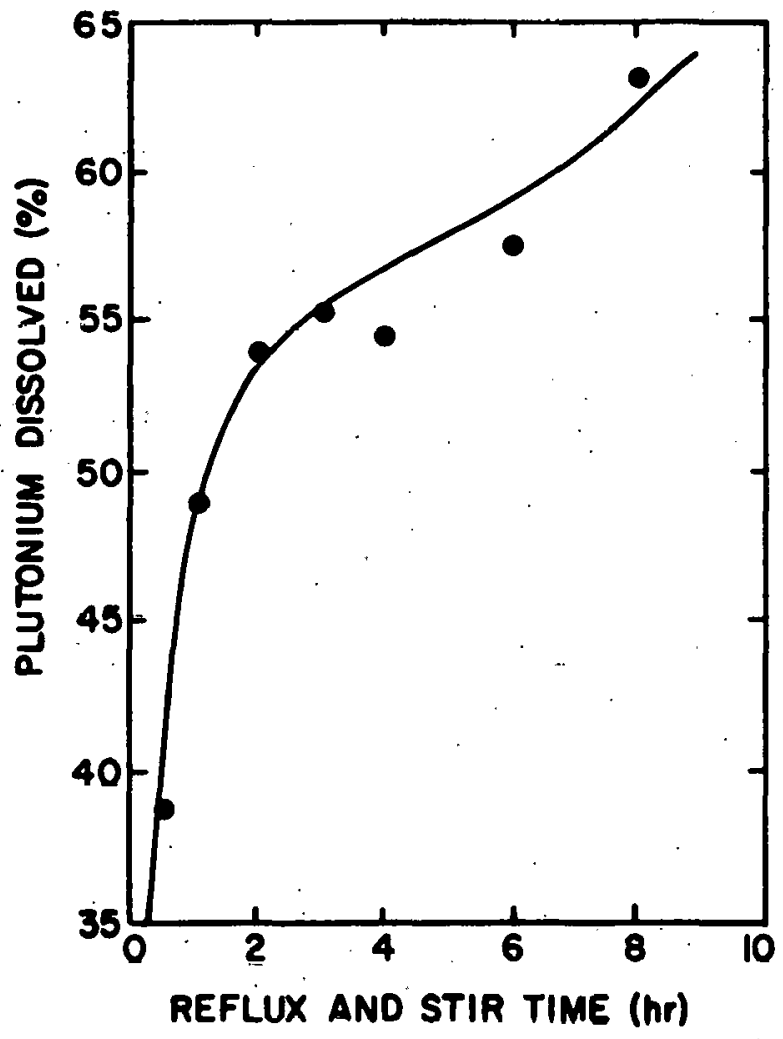

in 12.13M nitric acid at reflux temperatures and $6 \underline{M}$ nitric acid at room temperature.

Aluminum Nitrate and Boric Acid Addition: The addition of aluminum nitrate to complex the fluoride ion definitely aids the dissolution of impure plutonium tetrafluoride in refluxing nitric acid. This is shown in Figure 2 where the percent plutonium dissolved was

Table IV. The effect of nitric acid concentration on the dissolution of plutonium tetrafluoride. Reflux period: 2 hours, solid-to-llquid ratio: $250 \mathrm{~g} / \mathrm{l}$.

Nitric Acid Concentration, $\underline{M}$

Plutonium Diesolved, $\%$

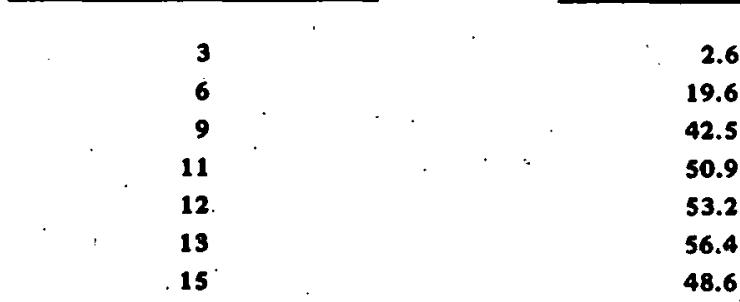

Figure 2. The effect of various concentrations of $\mathrm{Al}\left(\mathrm{NO}_{3}\right)_{3} \cdot 9 \mathrm{H}_{2} \mathrm{O}$ and nitric acid on the dissolution of plutonium tetranuoride (solid-toliquid ratio $250 \mathrm{~g} / \mathrm{l}$, reflux time 2 hours).

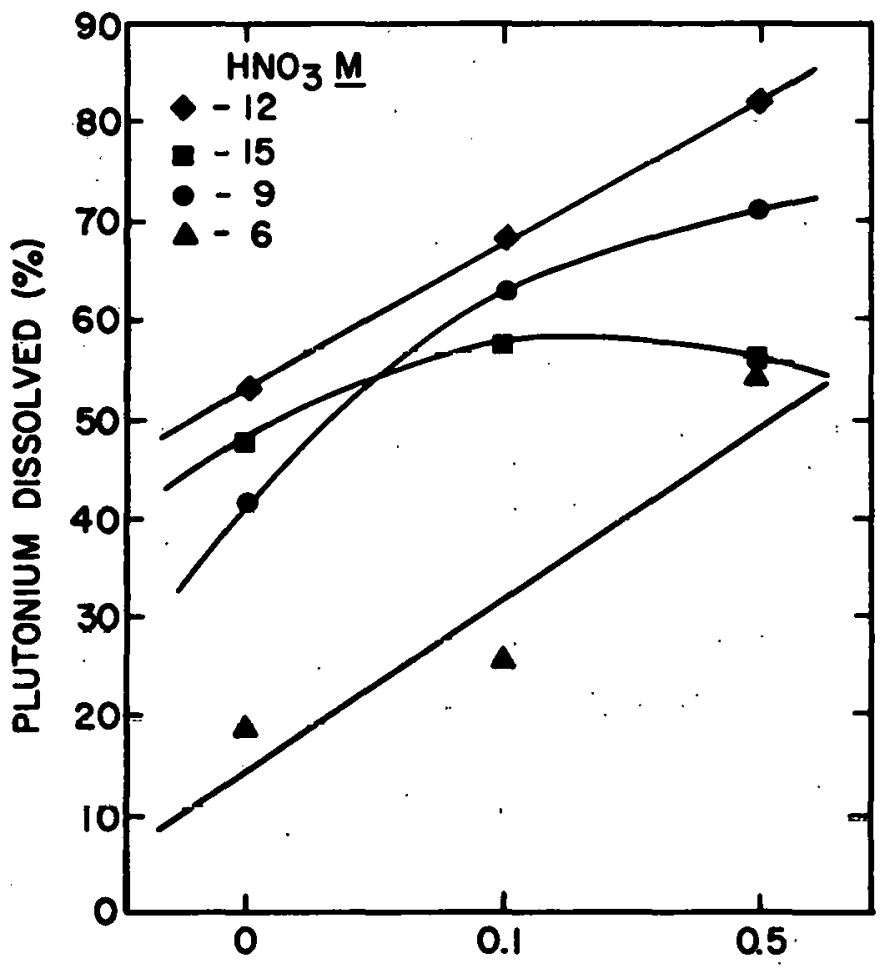

Al $\left(\mathrm{NO}_{3}\right)_{3} \cdot 9 \mathrm{H}_{2} \mathrm{O}$ CONCENTRATION (M) 
plotted as a function of both nitric acid concentration and aluminum nitrate concentration. Maximum dissolution was achieved in the $12 \underline{\mathrm{M}} \mathrm{HNO}_{3}-0.5 \underline{\mathrm{M} \mathrm{Al}}\left(\mathrm{NO}_{3}\right)_{3}$. $9 \mathrm{H}_{2} \mathrm{O}$ system.

The effects of two levels of boric acid and several different nitric acid concentrations on the dissolution of plutonium tetrafluoride are shown in Figure 3. Using $12 \mathrm{M} \mathrm{HNO}_{3}$ and $0.5 \mathrm{M} \mathrm{H}_{3} \mathrm{BO}_{3}$, dissolution of plutonium increased almost $30 \%$ as compared to using no $\mathrm{H}_{3} \mathrm{BO}_{3}$. Increasing .

Figure 3. The effect of various concentrations of boric acid and nitric acid on the dissolution of plutonium tetrafluoride (solid-to-liquid ratio $250 \mathrm{~g} / \mathrm{l}$, reflux time 2 hours).

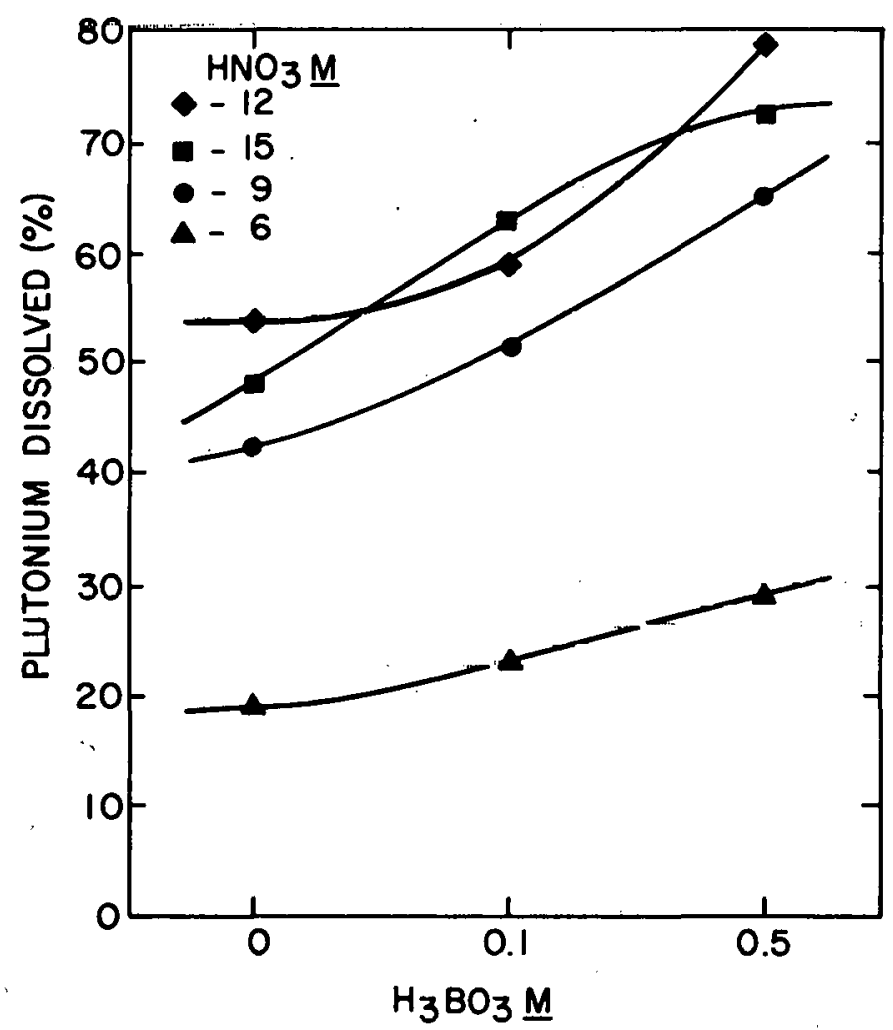

the boric acid concentration would probably increase the amount dissolved even further, especially in 12 to $15 \underline{M}$ $\mathrm{HNO}_{3}$ as found in previous work. ${ }^{1}$

In another study, ${ }^{2}$ other fluoride ion complexing agents (Al, B, Ca, Mg, Th and $\mathrm{Zr}$ ) were investigated for their relative effect on the dissolution of pure plutonium tetrafluoride. Under conditions of various nitric acid and complexing agent concentrations and $1 / 2,1$, and 2 hours of stirring at $25^{\circ}$ and $50^{\circ} \mathrm{C}$, the following conclusions were drawn: Boric acid is most effective in increasing dissolution, aluminum was second, calcium, magnesium, and thorium nitrates aided little in dissolution, and zirconium nitrate could not be accurately compared.

The addition of aluminum nitrate or boric acid to aid impure plutonium tetrafluoride dissolution on a production basis would contaminate the resultant solution with these reagento. Analyses of experinental $\mathrm{Pu}\left(\mathrm{NO}_{3}\right)_{4}$ solutions $(\sim 50 \mathrm{~g} / 1 \mathrm{Pu})$ using these agents resulted in detection of both aluminum and boron in the 2,00010,000 ppm range. After peroxide precipitation these agents would be removed. Leary, et al, ${ }^{3}$ for example report good purification of aluminum and boron from $\mathrm{Pu}\left(\mathrm{NO}_{3}\right)_{4}$ solutions by peroxide precipitation. Aluminum contamination was reduced from $500 \mathrm{ppm}$ to $\langle 5 \mathrm{ppm}$ and $B$ from $75 \mathrm{ppm}$ to $3 \mathrm{ppm}$.

\section{REFERENCES}

1. J. D. Navratil, "Dissolution of Plutonium Tetrafluoride in Nitric Acid," RFP-1 151, Rocky Flats Division. The Dow Chemical Company.

2. J. D. Navratil, "The Effect of Fluoride Ion Complexing Agents on the Dissolution of Plutonium Tetrafluoride." To be published. Rocky Flats Division, The Dow Chemical Company.

3. J. A. Leary, A. N. Morgan and W. J. Maraman, "Plutonium Peroxide Precipitation," Ind. and Eng. Chem., $51,27-31,1959$. 